\title{
Performance and egg quality of laying hens fed with mineral sources and rosemary oil
}

\author{
ELIS REGINA DE M. GARCIA ${ }^{1}$, NATÁLIA R.B. CHAVES ${ }^{1}$, CARLOS ANTONIO \\ L. DE OLIVEIRA ${ }^{2}$, CHARLES KIEFER ${ }^{3}$ and EVILÁSIO P. DE MELO ${ }^{4}$ \\ ${ }^{1}$ Universidade Estadual de Mato Grosso do Sul, Unidade Universitária de Aquidauana, Rodovia \\ Graziela Maciel Barroso, Km 12, 25, Zona Rural, 70200-000 Aquidauana, MS, Brazil \\ ${ }^{2}$ Departamento de Zootecnia, Universidade Estadual de Maringá, Av. Colombo, \\ 5790, Bloco J45, Zona 7, 87020-900 Maringá, PR, Brazil \\ ${ }^{3}$ Faculdade de Medicina Veterinária e Zootecnia, Universidade Federal de Mato Grosso do \\ Sul, Av. Senador Felinto Muller, 2443, 79070-900, Campo Grande, MS, Brazil
}

${ }^{4}$ Vet Science Nutracêuticos Ltda., Avenida Paranavaí, Parque Industrial Bandeirantes, 87070-130 Maringá, PR, Brazil

Manuscript received on June 12, 2018; accepted for publication on August 7, 2018

\begin{abstract}
How to cite: GARCIA ERDM, CHAVES NRB, OLIVEIRA CALD, KIEFER C AND MELO EPD. 2019. Performance and egg quality of laying hens fed with mineral sources and rosemary oil. An Acad Bras Cienc 91: e20180516. DOI 10.1590/0001-3765201820180516.
\end{abstract}

\begin{abstract}
In order to evaluate the effect of rosemary oil and micro mineral sources on the performance and egg quality of laying hens, 288 hens were used and distributed in a completely randomized design using a $2 \times 3$ factorial (mineral sources $x$ rosemary oil) with six different diets and six replications. Diets were formulated containing inorganic or organic minerals, with or without added rosemary oil (100 and $200 \mathrm{mg}$ $\mathrm{kg}-1)$. The treatments showed interaction for average egg weight, yolk color, albumen and yolk percentage, with significant results from the use of organic minerals compared to inorganic minerals. The addition of $200 \mathrm{mg} \mathrm{kg-1}$ rosemary oil in diets improved laying rate, egg mass, specific gravity, number of pores on the shell when compared to other treatments. In conclusion, the use of $200 \mathrm{mg} \mathrm{kg}-1$ of rosemary oil improves the performance of red laying hen eggs. The association between organic minerals and $100 \mathrm{mg}$ $\mathrm{kg}-1$ rosemary oil in laying hen diets increases yolk color and percentage of albumen. The use of organic minerals is superior to inorganic minerals as to improve the quality of eggs, increasing average egg weight, yolk color and percentage of albumen.
\end{abstract}

Key words: chelated mineral, feed intake, haugh unit, Rosmarinus officinalis, shell thickness.

\section{INTRODUCTION}

Mineral supplementation is used in layer diets to cut economic losses related to external egg quality and overcome one of the main nutritional limitations for this animal category, given that commercial feeds

Correspondence to: Elis Regina de Moraes Garcia

E-mail: ermgarcia@uems.br

ORCid: https://orcid.org/0000-0003-3739-2522 are based on maize and soybean meal - ingredients with low mineral concentration.

The mineral source to be supplemented is a factor to consider, as it is possible to find organic sources consisting of metallic ions bound to molecules such as amino acids, peptides and proteins. These sources show greater bioavailability when compared to the most commonly used inorganic sources such as oxides, sulfates and carbonates, and are added 
to diets at higher rates due to the uncertainties of absorption (Araújo et al. 2008).

Several studies on the full or partial replacement of inorganic sources by organic ones demonstrated that due to their superior bioavailability, organic minerals can improve the productive performance of hens (Richards et al. 2010) and eggshell quality, in addition to contributing to reduce micro mineral release onto the environment and environmental contamination (Osman et al. 2010).

Furthermore, the effect of minerals can be optimized due to synergism with other additives in the diet, including phenolic compounds found in essential oils and plant extracts. This demonstrates that this combination can be more efficient than individual use, considering that chelation between these compounds increase mineral absorption and use (Stef and Gergen 2012).

Phenolic compounds found in rosemary (Rosmarinus officinalis) such as caffeic acid can act as strong chelating agents with iron ions due to their chemical structure (Andjelkovic et al. 2006). Other phenolic compounds such as carnosol, carnosic acid and rosmarinic acid found in rosemary are capable of inhibiting bacterial growth, stimulating digestion and improving the absorption of nutrients in the diet (Al-Kassie et al. 2011). They also show intense antioxidant action (Traesel et al. 2011), and can be used as a replacement for synthetic antioxidants in feeds.

When added to layer feeds, the main active ingredients found in rosemary oil can improve egg production and eggshell quality (Çabuk et al. 2006), in addition to increasing weight (Al-Kassie et al. 2011) and egg mass, resulting in improved feed conversion ratio of hens (Radwan Nadia et al. 2008).

Therefore, the objective of this study was to evaluate the effects of the association between rosemary oil and mineral sources on performance and egg quality of red laying hens.

\section{MATERIALS AND METHODS}

The study was developed at the Aviculture Sector and Laboratory for Animal Product Quality of the State University of Mato Grosso do Sul, Aquidauana University Unit. A total of $288 \mathrm{Hy}$ Line Brown laying hens were used, at 30 weeks of age, during 112 days in four 28-day cycles. The procedures adopted in this study are certified by the Ethics Committee on Animal Use (CEUAIUEMS protocol 005/2013).

Hens were housed in conventional shed distributed in cages divided into four pens of two hens each (25 wide x 40 height x $45 \mathrm{~cm}$ deep), housing eight hens per cage. Feed and water were supplied ad libitum.

The light schedule adopted was 17 hours a day (natural + artificial lighting). Thermal conditions in the aviary were evaluated using a temperature and humidity sensor at 8 a.m. and 4 p.m., obtaining values for average temperature $\left(30.6^{\circ} \mathrm{C}\right)$, low temperature $\left(24^{\circ} \mathrm{C} \pm 0.8^{\circ} \mathrm{C}\right)$, high temperature $\left(35.8^{\circ} \mathrm{C} \pm 2.7^{\circ} \mathrm{C}\right)$ and relative air humidity $(83.8 \%$ $\pm 6 \%$ ), while also calculating the values of black globe temperature and moisture: ITGU (81.68) and thermal radiation load: CTR (476.63).

The experimental feeds were based on corn and soybean meal, and were formulated to contain equal energy and nutrient levels (Table I) and to supply the nutritional requirements of the hens, according to the genetic line management guide (Hy Line, 2014) and to Rostagno et al. (2011).

A completely randomized design was adopted in a 2 x 3 factorial (mineral sources x rosemary oil levels) with six treatments, six replications and eight hens per experimental unit.

The treatments consisted of six experimental diets with two trace mineral sources (inorganic or organic), three levels $\left(0,100\right.$, or $\left.200 \mathrm{mg} \mathrm{kg}^{-1}\right)$ of rosemary oil (RO), and three egg storage periods. The following diets were fed: D1 - diet supplemented with inorganic trace minerals (ITM) and no 
RO inclusion (conventional diet); D2 - diet supplemented with ITM and RO at $100 \mathrm{mg} \mathrm{kg}^{-1}$; D3 - diet supplemented with ITM and RO at 200 $\mathrm{mg} \mathrm{kg}^{-1}$; D4 - diet supplemented with organic trace minerals (OTM) and no RO inclusion; D5 - diet supplemented with OTM and RO at $100 \mathrm{mg} \mathrm{kg}^{-1}$; and D6 - diet supplemented with ITM and RO at $200 \mathrm{mg} \mathrm{kg}^{-1}$ (Table I).

Rosemary oil was added to the feeds in a powdered form, together with the mineral and vitamin supplements. The OTM supplement consisted of metal-amino acid complexes of $\mathrm{Cu}, \mathrm{Fe}, \mathrm{Mn}, \mathrm{Zn}$, and $\mathrm{Se}$ as selenium yeast. The different inclusion levels between the ITM and the OTM supplements are due to differences in their trace mineral levels. The ITM source contained copper sulfate $(\mathrm{Cu}, 25 \%)$, iron sulfate $(\mathrm{Fe}, 28 \%)$, manganese sulfate $(\mathrm{Mn}, 31 \%)$, sodium selenite (Se, 45\%), and zinc sulfate ( $\mathrm{Zn}, 35 \%$ ), and the OTM source contained copper chelate $(\mathrm{Cu}, 10 \%)$, iron chelate $(\mathrm{Fe}, 10 \%)$, manganese chelate $(\mathrm{Mn}$, $16 \%$ ), selenium proteinate (Se, $0.2 \%$ ), and zinc chelate $(\mathrm{Zn}, 16 \%)$. The various inclusion levels of the mineral and vitamin supplements containing inorganic or organic minerals are due to differences in mineral concentrations among the sources used.

Animal productive performance was evaluated through daily feed intake $\left(\mathrm{g} \mathrm{hen}^{-1}\right)$, laying rate, egg mass $\left(\mathrm{g} \mathrm{hen}^{-1}\right)$ and feed conversion ratio $\left(\mathrm{kg} \mathrm{kg}^{-1}\right.$ and $\left.\mathrm{kg} \mathrm{dz}^{-1}\right)$.

Feed intake was recorded weekly and calculated as the difference between the amount of feed provided and leftovers at the end of each week of the cycle.

Eggs were collected and counted daily, obtaining at the end of each cycle the total production of eggs, laying rate and egg mass for each experimental unit. Egg mass was obtained through the ratio between total production and average egg weight (total egg production $\mathrm{x}$ average egg weight) and was expressed in grams.
Feed conversion ratio was calculated by dividing the feed ingested $(\mathrm{kg})$ by total egg weight $(\mathrm{kg})$ and by the number of eggs produced $(\mathrm{dz})$, respectively, in each experimental unit.

To evaluate egg quality, six eggs were randomly selected in the last three days of each cycle in order to measure average weight $(\mathrm{g})$ and specific gravity $\left(\mathrm{g} \mathrm{cm}^{-3}\right)$. Of those, three eggs were used to evaluate shell thickness, percentages of shell, albumen, yolk, and yolk and albumen $\mathrm{pH}$. The remaining eggs were utilized to measure Haugh unit, yolk index $(\mathrm{mm})$ and raw yolk color.

Average egg weight was obtained based on the data on total weight and number of eggs in the experimental unit. The eggs destined for composition and $\mathrm{pH}$ analysis were weighed and cracked individually in nontoxic polystyrene containers, previously labeled and weighed, with total separation between albumen, yolk and shell. Each component was weighed separately and had its percentage calculated in relation to total egg weight; albumen, yolk and shell weight were divided by egg weight $(\mathrm{g})$ and the result was multiplied by 100 . Next, albumen and yolk $\mathrm{pH}$ were determined using a workbench $\mathrm{pH}$ meter (Hanna Instruments ${ }^{\circledR}$ ).

For quality analysis, the collected eggs were weighed individually using a semi-analytic balance $( \pm 0.001 \mathrm{~g})$ and later immersed in saline solution at different densities, ranging from 1.070 to 1.102 , to assess specific gravity. Egg density was determined to be the density at which the egg floated.

The eggs were broken on a flat and smooth glass surface. Using a digital pachymeter, albumen and yolk heights were measured and expressed in millimeters $(\mathrm{mm})$. Using the measurement of albumen height $(\mathrm{mm})$ and egg unit weight $(\mathrm{g})$, Haugh unit was calculated by the equation (1) described by Silversides and Budgell (2004):

$\mathrm{UH}=100 \log \left(\mathrm{H}+7,75-1,7 \mathrm{P}^{0,37}\right)$

In which, $\mathrm{H}=$ albumen height $(\mathrm{mm})$ and $\mathrm{P}=$ egg weight $(\mathrm{g})$. 
TABLE I

Percent and calculated compositions of experimental feeds.

\begin{tabular}{|c|c|c|c|c|c|c|}
\hline \multirow{3}{*}{ Ingredients } & \multicolumn{3}{|c|}{ Inorganic mineral } & \multicolumn{3}{|c|}{ Organic mineral } \\
\hline & \multicolumn{6}{|c|}{ Rosemary oil (mg kg-1) } \\
\hline & $\mathbf{0}$ & 100 & 200 & $\mathbf{0}$ & 100 & 200 \\
\hline Maize, grain & 62.08 & 62.08 & 62.08 & 62.08 & 62.08 & 62.08 \\
\hline Soybean meal, $45 \%$ & 25.34 & 25.34 & 25.34 & 25.34 & 25.34 & 25.34 \\
\hline Soybean oil & 0.45 & 0.45 & 0.45 & 0.45 & 0.45 & 0.45 \\
\hline Limestone & 9.97 & 9.97 & 9.97 & 9.97 & 9.97 & 9.97 \\
\hline Dicalcium phosphate & 1.09 & 1.09 & 1.09 & 1.09 & 1.09 & 1.09 \\
\hline L-lysine $\mathrm{HCl}$ & 0.01 & 0.01 & 0.01 & 0.01 & 0.01 & 0.01 \\
\hline DL-methionine & 0.22 & 0.22 & 0.22 & 0.22 & 0.22 & 0.22 \\
\hline Salt & 0.49 & 0.49 & 0.49 & 0.49 & 0.49 & 0.49 \\
\hline $\begin{array}{l}\text { Mineral and vitamin } \\
\text { supplement* }\end{array}$ & 0.15 & 0.15 & 0.15 & 0.35 & 0.35 & 0.35 \\
\hline Inert & 0.20 & 0.20 & 0.20 & 0.00 & 0.00 & 0.00 \\
\hline Total & 100.00 & 100.00 & 100.00 & 100.00 & 100.00 & 100.00 \\
\hline \multicolumn{7}{|l|}{ Calculated values } \\
\hline $\mathrm{EM}\left(\mathrm{kcal} \mathrm{kg}^{-1}\right)$ & 2.750 & 2.750 & 2.750 & 2.750 & 2.750 & 2.750 \\
\hline $\mathrm{PB}(\%)$ & 17.00 & 17.00 & 17.00 & 17.00 & 17.00 & 17.00 \\
\hline $\begin{array}{c}\text { Digestible methionine }+ \\
\text { cystine }(\%)\end{array}$ & 0.704 & 0.704 & 0.704 & 0.704 & 0.704 & 0.704 \\
\hline Digestible lysine (\%) & 0.774 & 0.774 & 0.774 & 0.774 & 0.774 & 0.774 \\
\hline Calcium (\%) & 4.20 & 4.20 & 4.20 & 4.20 & 4.20 & 4.20 \\
\hline Available phosphorus (\%) & 0.30 & 0.30 & 0.30 & 0.30 & 0.30 & 0.30 \\
\hline Linoleic acid (\%) & 1.60 & 1.60 & 1.60 & 1.60 & 1.60 & 1.60 \\
\hline
\end{tabular}

*Composition per kg of feed: Vitamin A, 7,500 IU; Vitamin D3 , 2,000 IU; Vitamin E, 10 IU; Vitamin K3 , 1.8 mg; Vitamin B1 , $1.5 \mathrm{mg}$; Vitamin B2 , $4.0 \mathrm{mg}$; Nicotinic acid, $25 \mathrm{mg}$; Pantothenic acid, $10 \mathrm{mg}$; Vitamin B6, $1.7 \mathrm{mg}$; Vitamin B12, $0.013 \mathrm{mg}$; Folic acid, 0.5 mg; Biotin, 0.05 mg; Choline, 220 mg; Cu, 11 mg; Fe, 55 mg; I, 1.1 mg; Mn, 77 mg; Se, 0.33 mg; Zn, 72 mg.

*Composition of inorganic trace mineral supplement (per kg): Vitamin A, 10 g; Vitamin D3 , 2.67 g; Vitamin E, 6.67 g; Vitamin K3 , 2.33 g; Vitamin B1 , 1.02 g; Vitamin B2 , 3.33 g; Nicotinic acid, 16.87 g; Pantothenic acid, 6.67 g; Vitamin B6, 1.40 g; Vitamin B12, 8.67 g; Folic acid, 0.40 g; Biotin, 1.67 g; Choline, 244.47 g; Cu, 29.33 g; Fe, 130.93 g; I, 1.20 g; Mn, 165.53 g; Se, 0.47 g; Zn, $137.13 \mathrm{~g}$; Vehicle, $229.8 \mathrm{~g}$.

*Composition of organic trace mineral supplement (per kg): Vitamin A, 4.29 g; Vitamin D3 , 1.14 g; Vitamin E, 2.86 g; Vitamin K3 , 1.0 g; Vitamin B1 , 0.44 g; Vitamin B2 , 1.43 g; Nicotinic acid, 7.23 g; Pantothenic acid, 2.86 g; Vitamin B6, 0.60 g; Vitamin B12, 3.71 g; Folic acid, 0.17 g; Biotin, 0.71 g; Choline, 104.77 g; Cu, 31.43 g; Fe, 157.14 g; I, 0.51 g; Mn, 137.51 g; Se, 47.14 g; Zn, $128.57 \mathrm{~g}$, Vehicle, $366.48 \mathrm{~g}$.

Later, horizontal yolk diameter was measured using a digital pachymeter $( \pm 0.05 \mathrm{~mm})$. The yolk index (mm) (height/diameter) was then calculated based on the average of the obtained values.

The analysis of raw yolk color was carried out using a DSM color fan (Yolk Color Fan)®, on a scale from 1 to 15 , ranging from light yellow to dark yellow (orange tonality).

Next, the eggshells were rinsed, air-dried for 48 hours, then weighed to determine external quality, through shell weight ( $\mathrm{g}$ ) and shell thickness (mm).

Shell thickness (including the membranes) was measured by reading four different points in 
the equatorial region, using a digital micrometer $( \pm$ $0.001 \mathrm{~mm}$ ), and transformed into an average value per experimental unit.

In the last cycle, 12 eggs were collected from each treatment to evaluate the geometrical variables and number of pores in the shell. The geometric variables, egg volume and area were determined according to the methodology proposed by Narushin (2005).

The number of pores in the shell in the different areas of the egg (apical, meridional and basal) was determined using the method set by Rahn (1981). The images were captured in a light microscope using Motic Images Plus ${ }^{\circledR}$ computerized image analysis software. Ten images were captured for each egg region, and the average number of pores was considered.

The data were subjected to the Shapiro-Wilk normality test. Analysis of variance was applied on those variables in which residuals showed a normal distribution, and averages were compared using test of Tukey $(\mathrm{P}<0.01$ and $\mathrm{P}<0.05)$. The generalized linear model was used for all other variables that did not show normal distribution, assuming a gamma distribution with inverse function and means compared by $\mathrm{T}$ Test $(\mathrm{P}<0.01$ and $\mathrm{P}<0.05)$.

\section{RESULTS AND DISCUSSION}

There was no interaction $(\mathrm{P}>0.05)$ between treatments for the variables related to the animal productive performance of the hens. Likewise, the different mineral sources did not influence $(\mathrm{P}>0.05)$ layer performance, evidencing that the organic and inorganic sources both met the nutritional needs and preserved the productive traits of the hens (Table II).

Likewise, Boruta et al. (2007), while replacing $8 \%, 17 \%$ and $33 \%$ of inorganic materials (copper, zinc, manganese and iron) with organic mineral sources in the feed of laying hens, did not see any changes in egg weight and mass, as well as production and feed conversion ratio. Similar results were also observed by Fernandes et al. (2008), who

TABLE II

Performance of red layers fed different mineral sources (MS) and rosemary oil levels (RO).

\begin{tabular}{|c|c|c|c|c|c|}
\hline \multirow{2}{*}{ Variables } & \multirow{2}{*}{$\begin{array}{l}\text { Feed intake } \\
\left(\mathrm{g} \mathrm{hen}^{-1}\right)\end{array}$} & \multicolumn{2}{|c|}{ Feed conversion ratio } & \multirow{2}{*}{$\begin{array}{c}\text { Laying } \\
\text { (\%) }\end{array}$} & \multirow{2}{*}{$\begin{array}{c}\text { Egg mass } \\
\left(\mathrm{g} \mathrm{hen}^{-1}\right)\end{array}$} \\
\hline & & $\left(\mathrm{kg} \mathrm{kg}^{-1}\right)$ & $\left(\mathrm{kg} \mathrm{dz}^{-1}\right)$ & & \\
\hline \multicolumn{6}{|l|}{ MS } \\
\hline Inorganic & 104.40 & 1.94 & 1.42 & 89.62 & 54.83 \\
\hline Organic & 103.61 & 1.90 & 1.40 & 89.52 & 54.82 \\
\hline \multicolumn{6}{|c|}{$\mathrm{RO}\left(\mathrm{mg} \mathrm{kg}^{-1}\right.$ of feed $)$} \\
\hline 0 & 104.05 & 1.95 & 1.44 & $88.13^{\mathrm{b}}$ & $54.09^{\mathrm{b}}$ \\
\hline 100 & 103.32 & 1.90 & 1.39 & $89.75^{\mathrm{ab}}$ & $54.83^{\mathrm{ab}}$ \\
\hline 200 & 104.65 & 1.91 & 1.40 & $90.83^{\mathrm{a}}$ & $55.55^{\mathrm{a}}$ \\
\hline Average $^{1}$ & 104.00 & 1.92 & 1.41 & 89.57 & 54.82 \\
\hline EPM & 0.50 & 0.01 & 0.01 & 0.44 & 0.23 \\
\hline Normality* & 0.143 & 0.604 & 0.433 & 1.581 & 0.622 \\
\hline \multicolumn{6}{|l|}{$P$-value } \\
\hline MS & 0.451 & 0.088 & 0.197 & 0.914 & 0.973 \\
\hline RO & 0.580 & 0.104 & 0.141 & 0.045 & 0.036 \\
\hline MS x RO & 0.433 & 0.200 & 0.388 & 0.510 & 0.298 \\
\hline
\end{tabular}

${ }^{1}$ Standard error of the mean; *Values with $\mathrm{P}>0.05$ show normal distribution by Shapiro-Wilk test; Different letters in the same column are significant at $5 \%$ probability. 
evaluated 0.250 and $0.500 \mathrm{ppm}$ of zinc, manganese and organic selenium in layer diets.

The results showed an isolated effect $(\mathrm{P}<0.05)$ of rosemary oil on laying rate and egg mass, in which the inclusion of $200 \mathrm{mg} \mathrm{kg}^{-1}$ of rosemary oil for both variables showed better results when compared to the other treatments (Table II).

These results are possibly related to the carnosic and rosmarinic acid found in rosemary, which may have increased the digestibility and use of diet nutrients due to their antimicrobial action and the fact they stimulate the secretion of pancreatic enzymes, increasing the production of gastric juice and pepsin (Al-Kassie et al. 2011).

The mineral sources and rosemary oil showed an interaction $(\mathrm{P}<0.01)$ for egg weight (Table III). When the hens were fed only inorganic mineral source, there was no influence of the addition of rosemary oil on egg weight; however, it was lower than the treatment containing organic mineral without rosemary oil supplementation. On the other hand, diets containing organic mineral source reduced egg weight when associated with $100 \mathrm{mg} \mathrm{kg}^{-1}$ of rosemary oil and in comparison to the inorganic source receiving the same level of rosemary oil. Both mineral sources showed similar egg weight when associated with $200 \mathrm{mg} \mathrm{kg}^{-1}$ of rosemary oil in diets. However, when analyzing the organic source in isolation, this level does not differ from the results obtained with the association of 0 and $100 \mathrm{mg} \mathrm{kg}^{-1}$ of rosemary oil (Table IV).

The higher egg weight attributed to the use of minerals in organic form in feeds without added rosemary oil may be related to the increase in yolk and albumen content, which in turn is the result of superior nutrient use by the hens, as observed by Fernandes et al. (2008) and Nunes et al. (2013).

When evaluating replacement levels (33\%, $66 \%$ and $100 \%$ ) of inorganic materials by organic sources in layer diets, Figueiredo Júnior et al. (2013) observed that 33\% replacement resulted in heavier eggs. Bölükbaş1 et al. (2008), when using essential oils (salvia, rosemary and thyme) in layer diets, observed that the addition of $200 \mathrm{mg} \mathrm{kg}^{-1}$

TABLE III

Quality of eggs from red layers fed different mineral sources (MS) and rosemary oil levels (RO).

\begin{tabular}{|c|c|c|c|c|c|c|}
\hline \multirow{2}{*}{ Variables } & \multirow{2}{*}{$\begin{array}{c}\text { Egg weight } \\
\text { (g) }\end{array}$} & \multirow{2}{*}{ Haugh unit } & \multirow{2}{*}{$\begin{array}{c}\text { Yolk index } \\
(\mathrm{mm})\end{array}$} & Yolk & Albumen & \multirow{2}{*}{ Yolk color } \\
\hline & & & & \multicolumn{2}{|c|}{ pH } & \\
\hline \multicolumn{7}{|l|}{ MS } \\
\hline Inorganic & 61.20 & 101.27 & 0.457 & 6.03 & 8.01 & 5.09 \\
\hline Organic & 61.26 & 101.03 & 0.458 & 6.03 & 8.01 & 5.05 \\
\hline \multicolumn{7}{|c|}{$\mathrm{RO}\left(\mathrm{mg} \mathrm{kg}^{-1}\right.$ of feed) } \\
\hline Control & 61.40 & 100.71 & 0.455 & 6.02 & 8.01 & 5.09 \\
\hline 100 & 61.10 & 100.98 & 0.457 & 6.05 & 8.00 & 5.17 \\
\hline 200 & 61.19 & 101.76 & 0.460 & 6.03 & 8.03 & 4.94 \\
\hline Average & 61.23 & 101.15 & 0.457 & 6.03 & 8.01 & 5.07 \\
\hline $\mathrm{EPM}^{1}$ & 0.21 & 0.25 & 0.00 & 0.01 & 0.01 & 0.03 \\
\hline Normality* & 0.579 & 0.168 & 0.181 & 0.348 & 0.294 & 0.792 \\
\hline \multicolumn{7}{|l|}{$P$-value } \\
\hline MS & 0.871 & 0.639 & 0.691 & 0.849 & 0.975 & 0.315 \\
\hline RO & 0.792 & 0.221 & 0.436 & 0.218 & 0.323 & $<0.01$ \\
\hline MS x RO & 0.005 & 0.505 & 0.661 & 0.333 & 0.696 & $<0.01$ \\
\hline
\end{tabular}

${ }^{1}$ Standard error of the mean; *Values with $\mathrm{P}>0.05$ show normal distribution by Shapiro-Wilk test; Different letters in the same column are significant at $1 \%$ and $5 \%$ probability. 
TABLE IV

Average egg weight of layers fed different mineral sources and rosemary oil levels.

\begin{tabular}{cccc}
\hline \multirow{2}{*}{ Mineral source } & \multicolumn{3}{c}{ Rosemary oil ( $\mathbf{m g ~ k g}^{-\mathbf{1}}$ of feed) } \\
\cline { 2 - 4 } & Control & $\mathbf{1 0 0}$ & $\mathbf{2 0 0}$ \\
\hline Inorganic & $60.53^{\mathrm{bA}}$ & $61.84^{\mathrm{aA}}$ & $61.22^{\mathrm{aA}}$ \\
Organic & $62.26^{\mathrm{aA}}$ & $60.35^{\mathrm{bB}}$ & $61.16^{\mathrm{aAB}}$ \\
\hline
\end{tabular}

Different lowercase letters in the same column and uppercase letters in the same row are significant at $1 \%$ probability.

of rosemary oil feed, as well as thyme, promoted higher egg weight. However, Çabuk et al. (2006) did not observe an effect of dietary supplementation with essential oils on that variable.

The interaction $(\mathrm{P}<0.01)$ between treatments evaluated for raw yolk color demonstrated that color was intensified with the use of organic minerals; however, the association between the inorganic mineral source and $100 \mathrm{mg} \mathrm{kg}^{-1}$ of rosemary oil increased yolk color when compared to the same mineral source combined with 0 and $200 \mathrm{mg} \mathrm{kg}^{-1}$ of rosemary oil (Table V).

The intensified color obtained from the use of organic minerals is likely related to superior absorption of minerals - including iron, which is responsible for the intense yellow color of yolk (Paik et al. 2009). The phenolic compounds found in the essential oils can also provide greater amounts of iron to hens, as they are able to chelate with the ions of this mineral and copper; the larger the amount of polyphenols, the more these minerals are absorbed and accumulate in the hen's liver (Stef and Gergen 2012). This explains the result found for yolk color with the use of inorganic materials and $100 \mathrm{mg} \mathrm{kg}^{-1}$ of rosemary oil.

Haugh unit, yolk index, and albumen and yolk $\mathrm{pH}$ were not influenced $(\mathrm{P}>0.05)$ by the evaluated treatments (Table III), corroborating the results found by Florou-Paneri et al. (2006), who while evaluating the effect of adding rosemary extract (5 and $10 \mathrm{~g} \mathrm{~kg}^{-1}$ ) and vitamin $\mathrm{E}$ on the performance and egg quality of laying hens, did not observe any effect on Haugh unit, yolk index, or eggshell
TABLE V

Raw yolk color of eggs of laying hens fed different mineral sources and rosemary oil levels.

\begin{tabular}{cccc}
\hline \multirow{2}{*}{ Mineral source } & \multicolumn{3}{c}{ Rosemary oil $\left(\mathbf{m g ~ k g}^{-\mathbf{1}}\right.$ of feed) } \\
\cline { 2 - 4 } & $\mathbf{0}$ & $\mathbf{1 0 0}$ & $\mathbf{2 0 0}$ \\
\hline Inorganic & $5.08^{\mathrm{bB}}$ & $5.32^{\mathrm{aA}}$ & $4.87^{\mathrm{bC}}$ \\
Organic & $5.10^{\mathrm{aA}}$ & $5.03^{\mathrm{bA}}$ & $5.01^{\mathrm{aA}}$ \\
\hline
\end{tabular}

Different lowercase letters in the same column and uppercase letters in the same row are significant at $1 \%$ probability.

thickness. Similar results were obtained by Saldanha et al. (2009) and Figueiredo Júnior et al. (2013), who did not observe any effect of the use of organic minerals in layer diets on internal egg quality.

In the percentage evaluation of egg components, an interaction $(\mathrm{P}<0.05)$ was detected among evaluated treatments only for the percentages of albumen and yolk (Table VI).

Rosemary oil supplementation did not alter the percentage composition of albumen in eggs with the use of organic mineral source. However, albumen percentage in eggs produced by layers fed with organic mineral was superior only to the treatment containing inorganic mineral not combined with rosemary oil. Layers fed the diet containing inorganic mineral source showed higher albumen deposition with the addition of $200 \mathrm{mg}$ $\mathrm{kg}^{-1}$ of rosemary oil in feed, so that this response was similar to hens supplemented with $100 \mathrm{mg} \mathrm{kg}^{-1}$ of rosemary oil, which for its part did not differ from the treatment that did not contain rosemary oil (Table VII).

These results infer that the supply of feeds containing organic mineral source may have favored the synthesis of proteins that compose the albumen (Pan et al. 2010), possibly due to greater mineral bioavailability. Moreover, the use of selenium in organic form in the diet of laying hens from 21 to 39 weeks of age promotes gland dilation and improved preservation of the ciliary epithelium of the magnum, isthmus and gland of 
TABLE VI

Quality of eggs from red layers fed different mineral sources (MS) and rosemary oil levels (RO).

\begin{tabular}{|c|c|c|c|c|c|c|c|c|}
\hline \multirow{2}{*}{ Variables } & Shell & Albumen & Yolk & \multirow{2}{*}{$\begin{array}{c}\text { Specific } \\
\text { gravity } \\
\mathrm{g} \mathrm{cm}^{-3}\end{array}$} & \multirow{2}{*}{$\begin{array}{c}\text { Shell } \\
\text { thickness } \\
(\mathbf{m m})\end{array}$} & \multirow{2}{*}{$\begin{array}{l}\text { Volume } \\
\left(\mathrm{cm}^{3}\right)\end{array}$} & \multirow{2}{*}{$\begin{array}{l}\text { Area } \\
\left(\mathrm{cm}^{2}\right)\end{array}$} & \multirow{2}{*}{$\begin{array}{l}\text { Pores } \\
\left(\mathrm{mm}^{2}\right)\end{array}$} \\
\hline & & $(\%)$ & & & & & & \\
\hline \multicolumn{9}{|l|}{ MS } \\
\hline Inorganic & 9.38 & 62.66 & 24.57 & 1.091 & 0.374 & 57.81 & 61.12 & $1.08^{\mathrm{a}}$ \\
\hline Organic & 9.47 & 62.65 & 24.65 & 1.090 & 0.377 & 57.64 & 61.14 & $0.97^{\mathrm{b}}$ \\
\hline \multicolumn{9}{|l|}{$\mathrm{RO}\left(\mathrm{mg} \mathrm{kg}^{-1}\right)$} \\
\hline Control & 9.43 & 62.29 & 24.68 & $1.086^{\mathrm{b}}$ & 0.374 & 57.42 & 60.98 & $1.02^{\mathrm{ab}}$ \\
\hline 100 & 9.48 & 62.52 & 24.74 & $1.090^{\mathrm{ab}}$ & 0.375 & 58.23 & 61.40 & $0.98^{\mathrm{b}}$ \\
\hline 200 & 9.37 & 63.14 & 24.35 & $1.096^{\mathrm{a}}$ & 0.377 & 57.52 & 61.00 & $1.08^{\mathrm{a}}$ \\
\hline Average & 9.42 & 62.65 & 24.61 & 1.090 & 0.375 & 57.72 & 61.12 & 1.02 \\
\hline $\mathrm{EPM}^{1}$ & 0.03 & 0.17 & 0.11 & 0.00 & 0.00 & 0.50 & 0.30 & 0.02 \\
\hline Normality* & 0.567 & 0.082 & 0.035 & $<0.01$ & 0.613 & $<0.01$ & $<0.01$ & $<0.01$ \\
\hline \multicolumn{9}{|l|}{ P-value } \\
\hline MS & 0.194 & 0.969 & 0.496 & 0.856 & 0.383 & 0.869 & 0.977 & $<0.01$ \\
\hline $\mathrm{AO}$ & 0.455 & 0.079 & 0.177 & 0.05 & 0.833 & 0.775 & 0.810 & $<0.01$ \\
\hline MS x RO & 0.704 & 0.012 & $<0.01$ & 0.472 & 0.152 & 0.325 & 0.321 & 0.647 \\
\hline
\end{tabular}

${ }^{1}$ Standard error of the mean; *Values with $\mathrm{P}>0.05$ show normal distribution by Shapiro-Wilk test; Different letters in the same column are significant at $1 \%$ and $5 \%$ probability.

TABLE VII

Percentage composition of albumen of eggs from laying hens fed different mineral sources and rosemary oil levels.

\begin{tabular}{cccc}
\hline \multirow{2}{*}{ Mineral source } & \multicolumn{3}{c}{ Rosemary oil $\left(\mathbf{m g ~ k g}^{-1}\right.$ of feed) } \\
\cline { 2 - 4 } & $\mathbf{0}$ & $\mathbf{1 0 0}$ & $\mathbf{2 0 0}$ \\
\hline Inorganic & $61.45^{\mathrm{bB}}$ & $62.57^{\mathrm{aAB}}$ & $63.30^{\mathrm{aA}}$ \\
Organic & $62.78^{\mathrm{aA}}$ & $62.31^{\mathrm{aA}}$ & $62.25^{\mathrm{aA}}$ \\
\hline
\end{tabular}

Different lowercase letters in the same column and uppercase letters in the same row are significant at $5 \%$ probability.

the shell, resulting in larger amounts of deposited albumen (Cavalcanti et al. 2009).

For the percentage of yolk in eggs, laying hens that received diets containing inorganic mineral did not show alterations in yolk deposition from added rosemary oil; however, hens not supplemented with rosemary oil showed greater deposition ability compared to those fed only organic minerals. The organic mineral source for this variable proved superior to the inorganic source only when associated with $100 \mathrm{mg} \mathrm{kg}^{-1}$ of rosemary oil (Table VIII).

Possibly, the beneficial effects of rosemary oil on digestibility (Al-Kassie et al. 2011) may have led to greater absorption of minerals and other nutrients in the diet, thus resulting in larger yolks.

A reduced albumen percentage in the eggs of laying hens raised in warm climate was reported by Bozkurt et al. (2012) following the supply of diets containing essential oils and mannanoligosaccharides. According to the authors, the use of these additives increased eggshell quality and, therefore, the hens were unable to maintain internal egg quality. The same was reported by Bölükbaşı et al. (2008), for yolk percentage values when layers were fed $200 \mathrm{mg} \mathrm{kg}^{-1}$ of rosemary oil and thyme.

There was no interaction between treatments $(\mathrm{P}>0.05)$ for the main traits of external egg quality (Table VI). However, the inclusion of $200 \mathrm{mg} \mathrm{kg}^{-1}$ feed of rosemary oil increased $(\mathrm{P}<0.05)$ the values of egg specific gravity.

To improve nutrient digestibility due to increased enzyme activity (Al-Kassie et al. 2011), the inclusion of rosemary oil in feeds may have also led to greater mineral retention, thus increasing the 
TABLE VIII

Percentage composition of yolk in eggs from laying hens fed different mineral sources and rosemary oil levels.

\begin{tabular}{cccc}
\hline \multirow{2}{*}{ Mineral source } & \multicolumn{3}{c}{ Rosemary oil (mg k $\mathbf{~ g}^{-1}$ of feed) } \\
\cline { 2 - 4 } & $\mathbf{0}$ & $\mathbf{1 0 0}$ & $\mathbf{2 0 0}$ \\
\hline Inorganic & $25.07^{\mathrm{aA}}$ & $24.38^{\mathrm{bA}}$ & $24.28^{\mathrm{aA}}$ \\
Organic & $24.25^{\mathrm{bB}}$ & $25.17^{\mathrm{aA}}$ & $24.57^{\mathrm{aAB}}$ \\
\hline
\end{tabular}

Different lowercase letters in the same column and uppercase letters in the same row are significant at $1 \%$ probability.

specific gravity values of eggs, but not enough to improve shell thickness.

While evaluating the supplementation of a blend of essential oils $\left(24 \mathrm{mg} \mathrm{kg}^{-1}\right)$ as a way to attenuate the adverse effects caused by seasonal thermic stress on the layer performance and egg quality, Bozkurt et al. (2012) observed an increase in weight, thickness and eggshell strength when compared to the control diet.

The inclusion of organic mineral source in feeds resulted in lower number of pores in the eggshell $(\mathrm{P}<0.01)$. On the other hand, the addition of $200 \mathrm{mg} \mathrm{kg}^{-1}$ of oil in the diets increased $(\mathrm{P}<0.01)$ the number of pores, with no difference from the treatment without added rosemary oil.

Pores are considered areas of incomplete crystallization during eggshell calcification, forming channels that penetrate the crystal layers and end in openings adjacent to the mammillary knobs (multiple cone-shaped structures) (Romanoff and Romanoff 1949).

Studies by Stefanello etal. (2014) demonstrated that growing supplementation with micro organic minerals $(\mathrm{Mn}, \mathrm{Zn}, \mathrm{Cu})$ in layer diets linearly reduced the number of mammillary knobs per $\mathrm{mm}^{2}$ of shell, indicating an improvement in eggshell quality given that high densities of mammillary knobs result in less resistant shells. As such, the decreased number of mammillary knobs likely resulted in the formation of pores, as these are formed between mammillary knobs.

Eggshell quality and formation are directly influenced by micro minerals such as zinc and copper, which are directly involved in the activation of the carbonic anhydrase and lysyl oxidase enzymes, respectively, which are responsible for forming the shell and collagen cross-links found in the organic membrane of the eggshell (Leeson and Summers 2001).

\section{CONCLUSIONS}

The use of $200 \mathrm{mg} \mathrm{kg}^{-1}$ of rosemary oil in feed contributed to improve animal productive performance in red layers.

The association between inorganic mineral source and $100 \mathrm{mg} \mathrm{kg}^{-1}$ of rosemary oil in the diets of laying hens improves egg quality, by increasing raw yolk color and albumen percentage.

The effects of organic minerals is superior to inorganic mineral source because it improves egg quality, increasing average weight, raw yolk color and albumen percentage.

\section{ACKNOWLEDGMENTS}

To the Conselho Nacional de Desenvolvimento Científico e Tecnológico (CNPq) and the Fundação de Apoio ao Desenvolvimento do Ensino, Ciência e Tecnologia do Estado de Mato Grosso do Sul (FUNDECT) for their financial support.

\section{REFERENCES}

AL-KASSIE GAM, ABD-AL-JALEEL RA AND MOHSEEN AM. 2011. The effect of a mixture of anise and rosemary on broiler performance. Agric Biol J N Am 2: 1279-1282.

ANDJELKOVIC M, CAMP JV, MEULENAER B, DEPAEMELAERE G, SOCACIU C, VERLOO M AND VERHE R. 2006. Iron-chelation properties of phenolic acids bearing catechol and galloyl groups. Food Chem 98: 23-31.

ARAÚJO JÁ, SILVA JHV, AMÂNCIO ALL, LIMA CB AND OLIVEIRA ERA. 2008. Fontes de minerais para poedeiras. Acta Vet Bras 2: 53-60.

BÖLÜKBAŞI SC, ERHAN MK AND KAYNAR O. 2008. The effect of feeding thyme, sage and rosemary oil on laying hen performance, cholesterol and some proteins ratio of egg yolk and Escherichia Coli count in feces. Arch Geflügelk 72: 231-237. 
BORUTA A, SWIERCZEWSKA E, GLEBOCKA K AND NOLLET L. 2007. Trace organic minerals as a replecement of inorganic sources for layers: effects on productivity and mineral excretion. Rev Cient Eletrônica Med Vet 13: 491494.

BOZKURT M, KÜÇÜKYILMAZ K, ÇATLI AU, ÇINAR M, BINTAŞ E AND ÇÖVEN F. 2012. Performance, egg quality, and immune response of laying hens fed diets supplemented with mannan-oligosaccharide or an essential oil mixture under moderate and hot environmental conditions. Poult Sci 91: 1379-1386.

ÇABUK M, BOZKURT M, ALCICEK A, CATH AU AND BASER KHC. 2006. Effect of a dietary essential oil mixture on performance of laying hens in the summer season. South Afr J Anim Sci 4: 215-22.

CAVALCANTI MBT, SILVA JL, CORREIA GMG, AGUIAR JFC, MEDEIROS JP AND EVÊNCIO NETO J. 2009. Avaliação dos aspectos produtivos e morfológicos do oviduto de poedeiras comerciais (Gallus gallus), tratadas com selênio orgânico. Arq Inst Biol 71:196-198.

FERNANDES JIM, MURAKAMI AE, SAKAMOTO MI, SOUZA LMG, MALAGUIDO A AND MARTINS EM. 2008. Effects of organic mineral dietary supplementation on production performance and egg quality of white layers. Rev Bras Cienc Avic 10: 59-65.

FIGUEIREDO JÚNIOR JP, COSTA FGP, GIVISIEZ PEN, LIMA MR, SILVA JHV, FIGUEIREDO-LIMA DF, SARAIVA EP AND SANTANA MHM. 2013. Substituição minerais inorgânicos por orgânicos na alimentação de poedeiras semipesadas. Arq Bras Med Vet Zootec 65: 513518.

FLOROU-PANERI P, DOTAS D, MITSOPOULOS L, DOTAS V, BOTSOGLOU E, NIKOLAKAKIS L AND BOTSOGLOU N. 2006. Effect of feeding Rosemary and a-Tocopheryl acetate on hen performance and egg quality. The J Poultry Sci 43: 143-149.

HY LINE. 2014. Manual de manejo poedeiras comerciais. 2014, 40 p. Disponível em: <http://www.hylinedobrasil. com.br/hyline/download/guia_brown_2014.pdf $>$. Acesso em: 02 abr. 2014.

LEESON S AND SUMMERS JD. 2001. Nutrition of the chickens, $4^{\text {th }}$ ed., Guelph: University Books, $591 \mathrm{p}$.

NARUSHIN VG. 2005. Egg geometry calculation using the measurements of length and breadth. Poult Sci 84: 482484.

NUNES JK, SANTOS VL, ROSSI P, ANCIUTI MA, RUTZ F, MAIER JC AND SILVA JGC. 2013. Qualidade de ovos e resistência óssea de poedeiras alimentadas com minerais orgânicos. Arq Bras Med Vet Zootec 65: 610-618.
OSMAN AMR, ABDEL WAHED HM AND RAGAB MS. 2010. Effects of supplementing laying hens diets with organic selenium on egg production, egg quality, fertility and hatchability. Egypt Poult Sci 30: 893-915.

PAIK I, LEE H AND PARK S. 2009. Effects of organic iron supplementation on the performance and iron content in the egg yolk of laying hens. J Poultry Sci 46: 198-202.

PAN EA, RUTZ F, DIONELLO NJL, ANCIUTI M AND KRABBE EL. 2010. Desempenho de poedeiras semipesadas arraçoadas com a suplementação de selênio orgânico. Rev Bras Agrociência 16: 83-89.

RADWAN NADIA L, HASSAN RA, QOTA EM AND FAYEK HM. 2008. Effect of natural antioxidant on oxidative stability of eggs and productive and reproductive performance of laying hens. Inter J Poultry Sci 7: 134-150.

RAHN H. 1981. Changes in shell conductance, pores, and physical dimensions of egg and shell during the first breeding cycle of turkey hens. Poult Sci 60: 2536-2541.

RICHARDS JD, ZHAO J, HARRELL RJ, ATWELL CA AND DIBNER JJ. 2010. Trace mineral nutrition in poultry and swine. Asian-Australas J Anim Sci 23: 15-27-1534.

ROMANOFF AL AND ROMANOFF AJ. 1949. The avian egg. New York: J Wiley \& Sons, 543 p.

ROSTAGNO HS, ALBINO LFT, DONZELE JL, GOMES PC, OLIVEIRA RF, LOPES DC, FERREIRA AS, BARRETO SLT AND EUCLIDES RF, 2011. Tabelas brasileiras para aves e suínos: composição de alimentos e exigências nutricionais, $3^{\mathrm{a}}$ ed., Viçosa: UFV, 252 p.

SALDANHA ESPB. GARCIA EA, PIZZOLANTE CC, FAITTARONE ABG, SECHINATO A, MOLINO AB AND LAGANÁ C. 2009. Effect of organic mineral supplementation on the egg quality of semi-heavy layers in their second cycle of lay. Rev Bras Cienc Avic 11: 215222.

SILVERSIDES FG AND BUDGELL K. 2004. The relationships among measures of egg albumen height, $\mathrm{pH}$, and whipping volume. Poult Sci 83: 1619-1623.

STEF DS AND GERGEN I. 2012. Effect of mineral-enriched diet and medicinal herbs on $\mathrm{Fe}, \mathrm{Mn}, \mathrm{Zn}$, and $\mathrm{Cu}$ uptake in chicken. Chemistry Central J 6: 2-9.

STEFANELLO C, SANTOS TC, MURAKAMI AE, MARTINS EN AND CARNEITO TC. 2014. Productive performance, eggshell quality, and eggshell ultrastructure of laying hens fed diets supplemented with organic trace minerals. Poult Sci 93: 104-113.

TRAESEL CK, LOPES, STA, WOLKMER P, SCHMIDT C, SANTURIO JM AND ALVES SH. 2011. Óleos essenciais como substituintes de antibióticos promotores de crescimento em frangos de corte: perfil de soroproteínas e peroxidação lipídica. Cienc Rural 41: 278-284. 